\title{
Soil Test based Phosphorus Nutrition as Cost Reduction Technology in Sugarcane
}

\author{
Ch.S. Rama Lakshmi*, A. Sireesha, T. Sreelatha, P. Jamuna and M. Bharatha Lakshmi \\ Regional Agricultural Research Station, Anakapalle, Visakhapatnam district-531001, India \\ *Corresponding author
}

\section{A B S T R A C T}

\begin{tabular}{|l|}
\hline Ke y w o r d s \\
$\begin{array}{l}\text { Phosphorus levels, } \\
\text { Nutrient uptake, } \\
\text { Juice quality, Cane } \\
\text { and sugar yield }\end{array}$ \\
\hline Article Info \\
\hline $\begin{array}{l}\text { Accepted: } \\
\text { 04 October } 2019 \\
\text { Available Online: } \\
\text { 10 November } 2019\end{array}$ \\
\hline
\end{tabular}

\section{Introduction}

Sugarcane in Andhra Pradesh is one of the important commercial crops grown in a wide variety of soils from sandy loams to deep black soils. Soil fertility levels also vary from place to place, particularly soil phosphorus status, it was low in clay soils and medium to high status in clay loams and high status in sandy loam soils. As a consequence of high

\begin{abstract}
A field experiment was conducted at Regional Agricultural Research Station, Anakapalle in plant - ratoon sequence with different levels of phosphorus and uniform recommended dose of nitrogen and potassium under high P clay loam soils of North Coastal Andhra Pradesh during 2014-2015 and 2015-2016. The aim of this present study is to reduce/optimize the phosphorus fertilizer doses under high $\mathrm{P}$ soils. Results revealed that, significantly highest cane yields of 76.90 and 67.90 tha $^{-1}$ was recorded with $70 \mathrm{~kg} \mathrm{P}_{2} \mathrm{O}_{5}$ $\mathrm{ha}^{-1}$ in plant and ratoon crops, respectively and it was on par with $50 \mathrm{~kg} \mathrm{P}_{2} \mathrm{O}_{5} \mathrm{ha}^{-1}$ (76.47 and $64.47 \mathrm{tha}^{-1}$, respectively). Significant sugar yield response was observed to increasing levels of $\mathrm{P}$ upto $50 \mathrm{~kg} \mathrm{P}_{2} \mathrm{O}_{5} \mathrm{ha}^{-1}$ and highest sugar yields of 11.0 tha $^{-1}$ and 8.80 tha $^{-1}$ were recorded with $50 \mathrm{~kg} \mathrm{P}_{2} \mathrm{O}_{5} \mathrm{ha}^{-1}$ in plant-ratoon sequence. Experimental results clearly indicating the role of $\mathrm{P}$ in juice quality enhancement as juice quality was increased with increasing levels of $\mathrm{P}$ from 0 to $50 \mathrm{~kg} \mathrm{P}_{2} \mathrm{O}_{5} \mathrm{ha}^{-1}$, later there was no significant changes in juice quality with increasing $\mathrm{P}$ levels up to100 $\mathrm{kg} \mathrm{P}_{2} \mathrm{O}_{5} \mathrm{ha}^{-1}$. Results clearly showing the synergistic effect of $\mathrm{P}$ on nutrient uptake and use efficiency of all the macro nutrients as evidenced with macro nutrient build up in soils with increasing P levels. The findings of this study would help in reduction of $50 \% \mathrm{P}$ fertilizer dose under high $\mathrm{P}$ soils for achieving desirable yield levels and will in turn reduce the expenditure on $\mathrm{P}$ fertilizers without compromising cane yield, sugar yield, juice quality and soil fertility status.
\end{abstract}

cost of water soluble chemically processed phosphatic fertilizers and poor $\mathrm{P}$ use efficiency due to fixation as insoluble phosphates, imbalance in NPK ratios are anticipated which eventually leads to reduced productivity of sugarcane. Continuous application of inorganic phosphate fertilizers along with available organic manures have accumulated residual available phosphorus exceeding levels needed for maximum crop 
yields. Knowledge of residual benefits from previously applied $\mathrm{P}$ is crucial to maximize economic returns to current $\mathrm{P}$ inputs. Many soils of the Visakhapatnam district contain available phosphorus concentrations above crop requirement due to continuous application of $\mathrm{P}$ fertilizers. Given that $\mathrm{P}$ is the most expensive primary nutrient on a unit basis in most cane producing areas, Sugarcane is capable of rapidly depleting the soil of nutrients, particularly $\mathrm{N}$ and $\mathrm{K}$, so phosphorus build up can be observed in fields with continuous $\mathrm{P}$ fertilization. Delineation of optimum $\mathrm{P}$ level for higher productivity and to avoid wastage of precious $\mathrm{P}$ fertilizer thus becomes inevitable. In an era of ever increasing economic constraints and community pressure to maintain the integrity of the environment, there is the need to fertilize efficiently (McCray et al., 2010). Over-application of fertilizers will not only affect the profitability of cane operations but also the loss of applied nutrients (Dodd and Sharpley, 2015 and Abdul Matin et al., 1997). The most important tool in phosphorus management for crops is a soil test. Soil testing reveals the soil phosphorus levels and determines the recommended application amount of phosphorus for the crop to be grown. Several researchers have demonstrated the beneficial effect of soil test based balanced nutrition for higher productivity and cost reduction (Bokhtiar et al., 2015). Consistent and representative soil sampling is very important for correct interpretation of soil test results. Soil testing is the most precise available tool to prescribe adequate $P$ fertilization rates (Doddand Sharpley, 2015). However, some reports suggest results can be erratic. There is a need to continue research on adjusting and validating soil $\mathrm{P}$ testing and $\mathrm{P}$ fertilization practices for improved productivity and reduced fertilizer costs. This study evaluated with different levels of $\mathrm{P}$ fertilization along with common dose of recommended nitrogen and potassium under high phosphorus soils on cane juice quality, cane yield, sugar yield, nutrient uptake, nutrient use efficiency and soil fertility in plant-ratoon sequence of sugarcane.

\section{Materials and Methods}

A field experiment was conducted at Regional Agricultural Research Station, Anakapalle, Andhra Pradesh in clay loams (Inceptisols) during 2014-2015 and 2015-2016 in plant ratoon sequence. The Experimental soils are neutral in reaction (7.33), non saline in conductivity $\left(0.538 \mathrm{dSm}^{-1}\right)$, medium in per cent organic carbon $(0.55 \%)$, low in available nitrogen $\left(252 \mathrm{~kg} \mathrm{ha}^{-1}\right)$ and high status of available phosphorus $\left(60.50 \mathrm{~kg} \mathrm{ha}^{-1}\right)$ and available potassium (389 $\mathrm{kg} \mathrm{ha}^{-1}$ ). Different graded levels of phosphotic fertilizers were tested along with common recommended dose of nitrogen and potassium fertilizers. The treatment details are as follows T1 :112-0-100 kg NPK ha-1), T2 : 112-17.5-100 kg NPK ha-1, T3 : 112-35-120 kg NPK ha-1), T4 : 112$52.50-120 \mathrm{~kg}$ NPK ha ${ }^{-1}$ ), T5 : 112-70-120 kg NPK ha ${ }^{-1}$ ) and T6 : 112-100-120kg NPKha ${ }^{-1}$ ). Experiment was laid out in a randomized block design with 4 replications. Sugarcane was planted (var. 2001A63) at $80 \mathrm{~cm}$ spacing in the first week of February, 2015 and subsequent ratoon crop was maintained in First week of January, 2016 and harvested in December, 2017. Recommended dose of nitrogen fertilizers were applied at 0 and 45 days and different levels of phosphorus and common dose of potassium was applied at the time of planting. Initial soil samples were collected before planting and post harvest soils were collected after harvest of plant and ratoon crops, subsequently. Whole plant samples for plant analysis were collected during grand growth stage of the crop. Chemical analysis of soil and plant samples was done as per the standard procedures described by Jackson (1967). The total nitrogen content $(\%)$ in the dried plant sample 
was determined by microkjeldahl distillation method (Piper, 1966). The diacid extract (9:4 nitric acid: perchloric acid) was used for analysis of total phosphorus, potassium and micronutrients in plant samples. Concentration of nutrient was multiplied by yield for calculation of nutrient uptake. Nutrient use efficiency in this paper is calculated by dividing the difference in uptake between treated and control by the rate of fertilizer applied. Juice analysis was carried out prior to harvesting, observations on Juice quality i.e. percent CCS, percent sucrose and percent purity was estimated as per the method suggested by Meade and Chen (1971). Cane yield was recorded during harvesting. Sugar yields were computed from the cane yield multiplied with \%CCS. In order to compare the effect of various treatments on yield and fertility status, Analysis of Variance (ANOVA) was performed using standard procedures for split plot design (Chandel 2002).

\section{Results and Discussion}

Effect of different graded levels of Phosphorus on Cane yield and Sugar yield

Data on cane yield, sugar yield and juice quality was presented in table 1. Among different levels of phosphorus, cane yields ranged between $68.92\left(0 \mathrm{~kg} \mathrm{P}_{2} \mathrm{O}_{5} \mathrm{ha}^{-1}\right)$ to $76.90 \mathrm{t} \mathrm{ha}^{-1}\left(70 \mathrm{~kg} \mathrm{P}_{2} \mathrm{O}_{5} \mathrm{ha}^{-1}\right)$. With increasing phosphorus levels cane yields were increased from $17.5 \mathrm{~kg} \mathrm{P}_{2} \mathrm{O}_{5} \mathrm{ha}^{-1}$ (73.16 tha ${ }^{-1}$ ) to $50 \mathrm{~kg}$ $\mathrm{P}_{2} \mathrm{O}_{5}$ ha $^{-1}\left(76.90\right.$ tha $\left.^{-1}\right)$, later further improvement in cane yields were not observed with increasing $\mathrm{P}$ levels. In sugarcane plant crop, significantly highest cane yield of 76.90 tha $^{-1}$ was recorded with $70 \mathrm{~kg} \mathrm{P}_{2} \mathrm{O}_{5} \mathrm{ha}^{-1}$ and it was on par with $50 \mathrm{~kg} \mathrm{P}_{2} \mathrm{O}_{5} \mathrm{ha}^{-1}$ (76.47 tha ${ }^{-1}$ ). Around 3.7 tha $^{-1}$ cane yield was increased from 25 to $75 \%$ increase in $\mathrm{P}$ fertilizer rates in plant crop. Subsequent ratoon crop recorded highest cane yield of $67.90 \mathrm{t} \mathrm{ha}^{-1}$ with $70 \mathrm{~kg}$
$\mathrm{P}_{2} \mathrm{O}_{5} \mathrm{ha}^{-1}$ and lowest yield of 54.92 tha $^{-1}$ was recorded in $0 \mathrm{~kg} \mathrm{P}_{2} \mathrm{O}_{5} \mathrm{ha}^{-1}$. Among different $\mathrm{P}$ levels, cane yields ranged between 59.16 (12.5 $\mathrm{kg} \mathrm{P}_{2} \mathrm{O}_{5} \mathrm{ha}^{-1}$ to $67.90 \mathrm{t} \mathrm{ha}^{-1}\left(70 \mathrm{~kg} \mathrm{P}_{2} \mathrm{O}_{5} \mathrm{ha}^{-1}\right)$, An additional cane yield of 0.38 and 3.03 tha $^{-1}$ in plant-ratoon sequence was achieved with a fertilizer dose of $100 \mathrm{~kg} \mathrm{P}_{2} \mathrm{O}_{5} \mathrm{ha}^{-1}$ (existing recommended fertilizer $\mathrm{P}$ dose) over $50 \mathrm{~kg}$ $\mathrm{P}_{2} \mathrm{O}_{5}$ ha $^{-1}$. Significant sugar yield response was observed to increasing levels of $\mathrm{P}$ upto 50 $\mathrm{kg} \mathrm{P}_{2} \mathrm{O}_{5} \mathrm{ha}^{-1}$ and highest sugar yields of $11.0 \mathrm{t}$ $\mathrm{ha}^{-1}$ and 8.80 tha $^{-1}$ were recorded with $50 \mathrm{~kg}$ $\mathrm{P}_{2} \mathrm{O}_{5} \mathrm{ha}^{-1}$ in plant-ratoon sequence. If " $\mathrm{P}$ " is omitted, reduction of 2.03 and 1.79 tha $^{-1}$ sugar yields in plant and ratoon crops, respectively was recorded. Among different P levels (17.5 \& $50 \mathrm{~kg}_{2} \mathrm{O}_{5} \mathrm{ha}^{-1}$ ) around 0.63 tha $^{-1}$ sugar yield gap was observed in plant crop, where as in ratoon crop it was 1.06 tha $^{-1}$. Mean sugar yields of 10.18 and 8.89 tha $^{-1}$ was recorded in plant and ratoon crops, respectively. Phosphorus (P) is essential for the synthesis of adenosine triphosphate and numerous other phosphorylated compounds (Ghube et al., 2017). This nutrient also enhances photosynthetic activity and increases root development, leading to increased nutrient uptake, greater tillering, and higher yield in sugarcane. $\mathrm{P}$ deficiency in sugarcane induces biochemical change such that leaf phosphatase acid activity is negatively correlated with accumulated P (McCray et al., 2017). Application of $\mathrm{P}$ fertilizer promotes root growth, stimulates tillering, influences milleable cane growth, and thereby sugarcane yield per ha (Pannu et al., 1985). Besides yield, adequate $\mathrm{P}$ nutrition is conducive for higher sugar accumulation in cane tissues. Kumar and Verma (1999) observed that application of $50 \mathrm{~kg} \mathrm{P}_{2} \mathrm{O}_{5} \mathrm{ha}^{-1}$ and above increased cane yield significantly over the control (37.2 to $56.4 \mathrm{t} \mathrm{ha}^{-1}$ ). Excessive use of $\mathrm{N}, \mathrm{P}$ or $\mathrm{K}$ can impact negatively on recoverable sugar and on the economics of cane production. About 10 to $20 \%$ of applied $\mathrm{P}$ is utilized, much less than that of other 
nutrients like N and K (Oseni 1978). Present experimental results clearly denoting the adjustment in phosphorus fertilizer doses by $50 \%$ reduction with the current recommended dose of $\mathrm{P}$ fertilizers i.e $100 \mathrm{~kg} \mathrm{P}_{2} \mathrm{O}_{5} \mathrm{ha}^{-1}$ under high $\mathrm{P}$ soils.

\section{Effect of different graded levels of Phosphorus on Cane Juice quality}

Experimental results indicating the role of $\mathrm{P}$ in juice quality enhancement as juice quality was increased with increasing levels of $\mathrm{P}$ from 0 to $50 \mathrm{~kg} \mathrm{P}_{2} \mathrm{O}_{5} \mathrm{ha}^{-1}$, later juice quality was slightly reduced with increasing $\mathrm{P}$ levels to $100 \mathrm{~kg}$ $\mathrm{P} 2 \mathrm{O} 5 \mathrm{ha}^{-1}$. Highest juice sucrose of 20.24 and $20.10 \%$ was recorded with $50 \mathrm{~kg} \mathrm{P}_{2} \mathrm{O}_{5} \mathrm{ha}^{-1}$ followed by $12.5 \mathrm{~kg} \mathrm{P}_{2} \mathrm{O}_{5} \mathrm{ha}^{-1}$ (20.13 and $19.85 \%)$ in plant and ratoon crops, respectively (Table 1). Lowest juice sucrose of 18.14 and $18.25 \%$ was recorded under $\mathrm{P}$ omitted plots. Percent Commercial Cane Sugar (CCS) varied from $13.02\left(0 \mathrm{~kg} \mathrm{P}_{2} \mathrm{O}_{5}\right.$ $\left.\mathrm{ha}^{-1}\right)$ to $14.37\left(0 \mathrm{~kg} \mathrm{P}_{2} \mathrm{O}_{5} \mathrm{ha}^{-1}\right)$ in plant and 12.77 to 13.50 in ratoon crops, respectively. Mean percent juice sucrose of 19.09 and 19.18 $\%$ in plant and 13.55 and $13.08 \%$ in ratoon crop was recorded. Among different phosphorus levels significant differences were not observed in juice quality parameters i.e juice sucrose and percent cane sugar, however highest juice sucrose and \% CCS was observed in phosphorus applied plots than phosphorus omitted plots. It is well established that a certain minimum $\mathrm{P}$ content in juice is essential for clarification because it is needed to react with lime to form a precipitate. Work at the different sugarcane research stations showed that poor sugar filterability was nearly always associated with high $\mathrm{P}$ contents in sugar (Lionnet1997). However, this could be caused by poor clarification often due to low levels or unreactive $P$ in juices, the residual $P$ then finding its way into the sugar, thus, low levels of $\mathrm{P}$ in juice can lead to high levels in sugar.
Further results from different investigations showed that locality has a highly significant impact on the $\mathrm{P}$ content of juice and is strongly influenced by soil and past fertilizer practices. This might be associated with the $\mathrm{P}$ may enhanced the activity of sucrose synthetase, which was responsible for sugar synthesis in sugarcane (Ghube et al., 2017). It is clearly indicating that phosphorus plays a major role in juice quality and clearly indicating that application of $50 \%$ of the recommended dose of phosphorus i.e. $50 \mathrm{~kg}$ $\mathrm{P}_{2} \mathrm{O}_{5} \mathrm{ha}^{-1}$ can meet the nutrient requirement without deteriorating juice quality under high $\mathrm{P}$ soils.

\section{Effect of different graded levels of Phosphorus on Nutrient Uptake}

The perusal of data presented in table 2 regarding nitrogen uptake by whole plant showed that increasing levels of $P$ significantly improved $\mathrm{N}$ uptake from 0 to 70 $\mathrm{kg} \mathrm{P}_{2} \mathrm{O}_{5}$ ha $^{-1}$. Highest uptake of total nitrogen in plant $\left(181 \mathrm{kgha}^{-1}\right)$ and ratoon crop (161 $\mathrm{kgha}^{-1}$ ) was recorded with application of 100 $\mathrm{kg} \mathrm{P}_{2} \mathrm{O}_{5} \mathrm{ha}^{-1}$ which was at par with $70 \mathrm{~kg} \mathrm{P}_{2} \mathrm{O}_{5}$ $\mathrm{ha}^{-1}$. Nitrogen uptake by whole plant ranged between 132 to $181 \mathrm{kgha}^{-1}$ in plant crop and 106 to $161 \mathrm{kgha}^{-1}$ in ratoon crop, respectively. Highest uptake was recorded with $100 \mathrm{~kg}$ $\mathrm{P}_{2} \mathrm{O}_{5}$ ha $^{-1}$ and lowest uptake was recorded in $\mathrm{P}$ omitted plots. Phosphorus uptake by plant crop was ranged between 51.2 to $64.9 \mathrm{kgha}^{-1}$ and 43.73 to $54.22 \mathrm{kgha}^{-1}$ in ratoon crop, respectively. Though highest uptake was recorded with $100 \mathrm{~kg} \mathrm{P}_{2} \mathrm{O}_{5} \mathrm{ha}^{-1}$, it was on par with $70 \mathrm{~kg} \mathrm{P}_{2} \mathrm{O}_{5} \mathrm{ha}^{-1}$ and $50 \mathrm{~kg} \mathrm{P}_{2} \mathrm{O}_{5} \mathrm{ha}^{-1}$. Highest potassium uptake by whole plant was 238 and $195 \mathrm{kgha}^{-1}$ in plant and ratoon crops, respectively, it was recorded in $70 \mathrm{~kg} \mathrm{P}_{2} \mathrm{O}_{5} \mathrm{ha}^{-}$ ${ }^{1}$ and it was on par with $50 \mathrm{~kg} \mathrm{P}_{2} \mathrm{O}_{5} \mathrm{ha}^{-1}$. Applications of fertilizers at optimum rate are responsible for greater root development followed by higher nutrient uptake and leaf area development that cause a significant 
improvement in yield (Rakkiyappan et al., 2007). Further, this might be due to increased $\mathrm{CO}^{2}$ assimilation resulting from increased nutrient uptake as reported in different studies (Mahajan et al., 2012 and Uddin et al., 2013).

It may be due to the higher concentration of $\mathrm{N}$, $\mathrm{P}$ and $\mathrm{K}$ in stalks and dry matter accumulation that led to higher $\mathrm{N}, \mathrm{P}$ and $\mathrm{K}$ uptake at higher level of fertilizers application. Improvement in $\mathrm{N}, \mathrm{P}$ and $\mathrm{K}$ uptake by crop was reported with increased P levels (Sandhu and Mahal, 2014 and Gangadevi et al., 2012, Sanusan et al., 2009 and Yuanqiu et al., 2007) and NPK levels (Arif et al., 2010 and Sandhyakanthi et al., 2014). Morris et al., (2002) reported that $\mathrm{P}$ was an essential plant nutrient that contributed to optimum sugarcane yield. Thangavelu and Chiranjivi Rao (2002) reported that P uptake by dry leaves, green tops, stem and total uptake in above ground parts was associated positively with uptake of $\mathrm{N}$ and $\mathrm{K}$ and yield of cane and sugar at harvest. Alexander et al., (2003) reported that N, P and K application beyond 100 per cent of the recommended dose had produced only marginal increase in cane and sugar yield. Information on nutrient uptake and nutrient use efficiency of sugarcane clones are essential for efficient nutrient management (Schumann et al., 1998).

Effect of different graded levels of Phosphorus on Nutrient Use Efficiency

In sugarcane plant-ratoon sequence, Nitrogen Use Efficiency was increased with increasing levels of phosphorus and highest $\mathrm{N}$ use efficiency of 43.75 and $40.33 \%$ was recorded with $100 \mathrm{~kg} \mathrm{P}_{2} \mathrm{O}_{5} \mathrm{ha}^{-1}$ in plant and ratoon crops, respectively and it was on par with 70 $\mathrm{kg} \mathrm{P}_{2} \mathrm{O}_{5} \mathrm{ha}^{-1}(41.07 \%)$ in plant and $50 \mathrm{~kg}$ $\mathrm{P}_{2} \mathrm{O}_{5}$ ha $^{-1}(39.64 \%)$ in ratoon crop, respectively.

Significantly lowest nitrogen use efficiency of 24.11 and $28.93 \%$ was recorded with $17.5 \mathrm{~kg}$
$\mathrm{P}_{2} \mathrm{O}_{5} \mathrm{ha}^{-}$in plant and ratoon crops, respectively (Table 2). Results clearly showing the synergistic effect of $\mathrm{P}$ on nitrogen uptake and use efficiency. Similar results were report by Mahajan et al., (2012).

Mean nitrogen use efficiency of 34.46 and $37.40 \%$ was observed in plant and ratoon crops, respectively. Phosphorus Use Efficiency was highest with lower rates of $\mathrm{P}$ application and low at higher rates of $\mathrm{P}$ application in plant crop but in ratoon crop reverse trend was observed as it was high under high $\mathrm{P}$ levels when compared to low levels.

In plant crop, it clearly shows the increasing fertilizer efficiency under high soil $\mathrm{P}$ status with booster dose of reduced recommended application. Reverse trend in ratoon crop is due to high nutrient requirement by ratoon crop compared to plant crop, hence lower levels can't meet the nutrient requirement coupled with low nutrient use efficiency (Bationoand Anand Kumar 2002). P Use Efficiency varied from 12.86 to $22.86 \%$ in plant and 6.11 to $16.16 \%$ in ratoon crops, respectively. Highest use efficiency in plant crop was observed with $17.5 \mathrm{~kg} \mathrm{P}_{2} \mathrm{O}_{5} \mathrm{ha}^{-1}$, where as in ratoon crop highest efficiency was observed with $75 \mathrm{~kg} \mathrm{P}_{2} \mathrm{O}_{5} \mathrm{ha}^{-1}$. Larger uptake is possible because roots can absorb $\mathrm{P}$ from solutions with very small $\mathrm{P}$ concentrations and $\mathrm{P}$ is maintained in solution by desorption from the solid phase of the soil. Provided Efficiency of soil and fertilizer phosphorus use that there is sufficient $\mathrm{P}$ on adsorption sites, from which it can be desorbed readily, and that the rate of release is adequate, plants will obtain enough $\mathrm{P}$ to meet their changing demand during the growing season (Halvorson 1985), mean $\mathrm{P}$ Use Efficiency of 16.09 and $12.55 \%$ was observed in plant and ratoon crops, respectively. Potassium Use Efficiency varied from 36 to $55 \%$ in plant crop and 48 to $66 \%$ in ratoon crop. 
Table.1 Effect of graded levels of soil test based phosphorus management cane juice quality and yield of sugarcane

\begin{tabular}{|c|c|c|c|c|c|c|c|c|}
\hline \multirow[t]{2}{*}{ Treatments } & \multicolumn{2}{|c|}{$\%$ Juice sucrose } & \multicolumn{2}{|c|}{$\% \mathrm{CCS}$} & \multicolumn{2}{|c|}{ Cane yield (t/ha) } & \multicolumn{2}{|c|}{$\begin{array}{c}\text { Sugar yield } \\
\text { (t/ha) }\end{array}$} \\
\hline & Plant & Ratoon & Plant & Ratoon & Plant & Ratoon & Plant & Ratoon \\
\hline T1:(112-0-120 kg NPK ha-1) & 18.14 & 18.25 & 13.02 & 12.77 & 68.92 & 54.92 & 8.97 & 7.01 \\
\hline T2:(112-17.5-120 kg NPK ha-1) & 20.13 & 19.85 & 14.18 & 13.24 & 73.16 & 59.16 & 10.37 & 7.83 \\
\hline T3:(112-35-120 kg NPK ha $\left.{ }^{-1}\right)$ & 18.94 & 19.05 & 13.42 & 12.87 & 75.42 & 62.42 & 10.35 & 8.03 \\
\hline T4:(112-50-120 kg NPK ha-1) & 20.24 & 20.10 & 14.37 & 13.50 & 76.47 & 64.47 & 11.00 & 8.80 \\
\hline T5:(112-70-120 kg NPK ha-1) & 18.30 & 19.15 & 13.10 & 13.10 & 76.90 & 67.90 & 10.17 & 8.81 \\
\hline T6:(112-100-120 kg NPK ha $\left.{ }^{-1}\right)$ & 18.80 & 18.70 & 13.31 & 12.98 & 76.85 & 67.50 & 10.20 & 8.71 \\
\hline Mean & 19.09 & 19.18 & 13.55 & 13.08 & 74.62 & 62.70 & 10.18 & 8.20 \\
\hline S.Em \pm & 0.45 & 0.36 & - & 0.19 & 2.43 & 2.15 & 0.475 & 0.33 \\
\hline CD (0.05) & 0.86 & 0.78 & NS & 0.40 & 5.53 & 4.25 & 1.090 & 0.75 \\
\hline CV (\%) & 7.60 & 8.48 & - & 8.20 & 8.55 & 8.90 & 6.57 & 8.10 \\
\hline
\end{tabular}

\begin{tabular}{|c|c|c|c|c|c|c|c|c|c|c|c|c|}
\hline \multirow[t]{3}{*}{ Treatments } & \multicolumn{6}{|c|}{ Nutrient uptake $(\mathrm{kg} / \mathrm{ha})$} & \multicolumn{6}{|c|}{ Nutrient Use Efficiency (\%) } \\
\hline & \multicolumn{3}{|c|}{ Plant } & \multicolumn{3}{|c|}{ Ratoon } & \multicolumn{3}{|c|}{ Plant } & \multicolumn{3}{|c|}{ Ratoon } \\
\hline & $\mathrm{N}$ & $\mathrm{P}$ & $\mathrm{K}$ & $\mathrm{N}$ & $\mathrm{P}$ & $\mathrm{K}$ & $\mathrm{N}$ & $\mathrm{P}$ & $\mathrm{K}$ & $\mathrm{N}$ & $\mathrm{P}$ & $\mathrm{K}$ \\
\hline $\begin{array}{l}\text { T1: (112-0-120 } \\
\left.\text { kg NPK ha-1) }^{-1}\right)\end{array}$ & 132 & 51.2 & 165 & 106 & 43.73 & 129 & - & - & - & - & - & - \\
\hline $\begin{array}{l}\text { T2: }(112-17.5- \\
\left.120 \mathrm{~kg} \mathrm{NPK} \mathrm{ha}^{-1}\right)\end{array}$ & 159 & 55.2 & 211 & 142 & 47.10 & 177 & 24.11 & 22.86 & 36.00 & 28.93 & 6.11 & 48.00 \\
\hline $\begin{array}{l}\text { T3: (112-35-120 } \\
\left.\text { kg NPK ha- }^{-1}\right)\end{array}$ & 166 & 56.4 & 234 & 148 & 49.70 & 182 & 30.36 & 14.86 & 42.00 & 41.57 & 10.59 & 53.00 \\
\hline $\begin{array}{c}\text { T4: }(112-50-120 \\
\left.\text { kg NPK ha }^{-1}\right)\end{array}$ & 169 & 59.7 & 232 & 151 & 51.33 & 195 & 33.04 & 16.19 & 45.00 & 39.64 & 12.73 & 64.00 \\
\hline $\begin{aligned} \text { T5: } & (112-70-120 \mathrm{~kg} \\
& \text { NPK ha-1) }\end{aligned}$ & 178 & 60.2 & 230 & 159 & 54.06 & 190 & 41.07 & 12.86 & 53.00 & 36.52 & 17.16 & 61.00 \\
\hline $\begin{array}{l}\text { T6: }(112-100-120 \\
\left.\text { kg NPK ha-1) }^{-1}\right)\end{array}$ & 181 & 64.9 & 238 & 161 & 54.22 & 193 & 43.75 & 13.70 & 55.00 & 40.33 & 16.16 & 66.00 \\
\hline Mean & 168 & 57.9 & 225 & 149 & 50.02 & 185 & 34.46 & 16.09 & 46.20 & 37.40 & v12.55 & 58.40 \\
\hline S.Em ${ }^{+}$ & 5.80 & 2.11 & & & 1.22 & 4.88 & 1.45 & 0.47 & 1.57 & 1.31 & 0.56 & 2.15 \\
\hline CD (0.05) & 12.5 & 4.62 & NS & NS & 3.15 & 12.2 & 2.95 & 0.98 & 3.9 & 2.75 & 1.08 & 4.5 \\
\hline CV (\%) & 8.22 & 9.20 & & & 9.65 & 11.00 & 7.40 & 8.10 & 7.50 & 8.10 & 7.25 & 7.90 \\
\hline
\end{tabular}


Table.3 Soil physicochemical properties of post harvest soils under different phosphorus levels

\begin{tabular}{|c|c|c|c|c|c|c|c|c|c|c|c|c|}
\hline \multirow[t]{3}{*}{ Treatments } & \multicolumn{2}{|c|}{ pH } & \multicolumn{2}{|c|}{ EC $(d S / m)$} & \multicolumn{2}{|c|}{$\mathrm{OC}(\%)$} & \multicolumn{6}{|c|}{$\begin{array}{c}\text { Available macronutrients } \\
\left(\mathrm{kg} \mathrm{ha}^{-1}\right)\end{array}$} \\
\hline & \multirow[t]{2}{*}{ Plant } & \multirow[t]{2}{*}{ Ratoon } & \multirow[t]{2}{*}{ Plant } & \multirow[t]{2}{*}{ Ratoon } & \multirow[t]{2}{*}{ Plant } & \multirow[t]{2}{*}{ Ratoon } & \multicolumn{3}{|c|}{ Plant } & \multicolumn{3}{|c|}{ Ratoon } \\
\hline & & & & & & & $\mathrm{N}$ & $\mathrm{P}_{2} \mathrm{O}_{5}$ & $\mathrm{~K}_{2} \mathrm{O}$ & $\mathrm{N}$ & $\mathrm{P}_{2} \mathrm{O}_{5}$ & $\mathrm{~K}_{2} \mathrm{O}$ \\
\hline Initial & 7.33 & & 0.538 & & 0.55 & & 252 & 60.50 & 389 & & & \\
\hline T1 & 7.49 & 6.96 & 0.431 & 0.731 & 0.53 & 0.59 & 251 & 56.60 & 381 & 236 & 52.35 & 280 \\
\hline T2 & 7.48 & 6.92 & 0.416 & 0.734 & 0.59 & 0.57 & 254 & 61.32 & 381 & 241 & 64.74 & 314 \\
\hline T3 & 7.19 & 6.94 & 0.514 & 0.690 & 0.54 & 0.55 & 255 & 66.92 & 392 & 248 & 72.13 & 325 \\
\hline T4 & 7.32 & 7.06 & 0.339 & 0.445 & 0.57 & 0.54 & 268 & 69.28 & 403 & 257 & 74.59 & 302 \\
\hline T5 & 7.56 & 6.76 & 0.283 & 0.375 & 0.60 & 0.61 & 266 & 75.52 & 437 & 254 & 75.04 & 336 \\
\hline T6 & 7.48 & 6.56 & 0.546 & 0.323 & 0.54 & 0.56 & 283 & 76.20 & 395 & 263 & 79.07 & 347 \\
\hline Mean & 7.42 & 6.87 & 0.422 & 0.550 & 0.56 & 0.57 & 263 & 67.64 & 398 & 250 & 70.79 & 317 \\
\hline S.Em \pm & & & & & & 0.125 & 5.91 & 2.98 & 9.54 & 5.05 & 1.96 & 9.45 \\
\hline CD $(0 . \overline{05})$ & NS & NS & NS & NS & NS & 0.036 & 12.90 & 5.22 & 21.22 & 11.65 & 4.01 & 22.00 \\
\hline CV (\%) & - & - & - & - & - & 7.50 & 10.73 & 8.94 & 7.38 & 11.50 & 9.12 & 8.56 \\
\hline
\end{tabular}

Highest use efficiency was recorded with 100 $\mathrm{kg} \mathrm{P}_{2} \mathrm{O}_{5} \mathrm{ha}^{-1}$ and lowest efficiency was recorded with $12.5 \mathrm{~kg} \mathrm{~kg} \mathrm{P}_{2} \mathrm{O}_{5} \mathrm{ha}^{-1}$. Mean KUE of plant -ratoon sequence was 46.20 and $58.40 \%$, respectively. Though nitrogen and potassium levels are same in all the treatments, variation in uptake and use efficiency among different treatments is due to synergistic effect of $\mathrm{P}$ with other macro nutrients. Phosphorus $(\mathrm{P})$ deficiency is a major constraint to crop production and response to nitrogen $(\mathrm{N})$ is substantial only when $\mathrm{P}$ is not limiting (Traore 1974). As per the Jagmanet al., (2017) Phosphorus use efficiency estimated for the world using the difference method was $16 \%$. Du Toit (1962) reported that where ratoons had received somewhat excessive amounts of phosphate, the effect of $\mathrm{P}$ in lowering sucrose per cent cane was most pronounced, particularly in later ratoons, which had received the topdressing.

\section{Effect of different graded Levels of Phosphorus on Soil fertility status}

Post harvest soils are neutral in reaction with normal conductivity, there is no significant difference between soil reaction and electrical conductivity in between different $\mathrm{P}$ levels in plant-ratoon sequence. Significantly highest organic content of $0.61 \%$ was recorded in the plots which received $70 \mathrm{~kg} \mathrm{P}_{2} \mathrm{O}_{5} \mathrm{ha}^{-1}$ in ratoon crop from its initial value of $0.55 \%$. However significant differences were not observed in post harvest soils of plant crop (Table 3 ). The results in the present study revealed that available nitrogen, available phosphorus and available potassium were built up in soils with increasing $\mathrm{P}$ levels compared to $\mathrm{P}$ omitted plots. The findings were in line with the results obtained by Rene et al., (2017). In post harvest soils of sugarcane plant crop, significantly highest available nitrogen content of $283 \mathrm{~kg} \mathrm{ha}^{-1}$ was recorded with $100 \mathrm{~kg} \mathrm{P}_{2} \mathrm{O}_{5}$ $\mathrm{ha}^{-1}$ and lowest content of $251 \mathrm{~kg} \mathrm{ha}^{-1}$ was recorded in $\mathrm{P}$ omitted plots. In ratoon crop also same trend was followed as it was significantly highest $\left(263 \mathrm{kgha}^{-1}\right)$ with $100 \mathrm{~kg}$ $\mathrm{P}_{2} \mathrm{O}_{5} \mathrm{ha}^{-1}$ and lowest $\left(236 \mathrm{~kg} \mathrm{ha}^{-1}\right)$ with $\mathrm{P}$ omitted plots, might be due to synergistic effect of $\mathrm{N}$ and $\mathrm{P}$ (Rene et al., 2017). Available phosphorus content varied from 56.60 to $76.20 \mathrm{kgha}^{-1}$ in plant crop and 52.35 to $79.79 \mathrm{~kg} \mathrm{ha}^{-1}$ in ratoon crop, respectively. Available $\mathrm{P}$ content increased with increasing levels of phosphorus and significantly highest 
content was recorded with $100 \mathrm{~kg} \mathrm{P}_{2} \mathrm{O}_{5} \mathrm{ha}^{-1}$ and lowest content was recorded with $\mathrm{P}$ omitted plots. Available potassium status also followed the same trend as it was high with high $\mathrm{P}$ levels and low with $\mathrm{P}$ omitted plots. Synergistic interactions are well known for $\mathrm{N}$ $\mathrm{x} \mathrm{P}$ and $\mathrm{N} \times \mathrm{K}$ interactions in several studies conducted all over India (Aulakh and Malhi 2005 and Roy et al., 2006).

The findings of this study would help in efficient use of $\mathrm{P}$ fertilizer for achieving desirable yield levels and will in turn reduce the expenditure on $\mathrm{P}$ fertilizers that are mostly imported by India and majority of other developing countries. Due to high removal of nutrients by the sugarcane crop, nutrient supply capacity of the soil must be known for balanced fertilizer application for achieving sustainable yields by soil test results. Balanced fertilizer application based on soil test results provide greatest opportunity for improving the nutrient use efficiency and cane yield without deterioration of cane juice quality and soil fertility. The findings of this study would help in $50 \%$ reduction of $\mathrm{P}$ fertilizer dose under high $\mathrm{P}$ soils for achieving desirable yield levels and will in turn reduce the expenditure on $\mathrm{P}$ fertilizers without compromising cane yield, sugar yield, juice quality and soil fertility status.

\section{Acknowledgements}

The authors would like to thank the Acharya N G Ranga Agricultural University for execution of research work at Regional Agricultural Research Station, Anakapalle by providing financial support.

\section{References}

Abdul Matin, Kazuhlro OYA, Toshlya S and Tsuyoshl H (1997). Phosphorus Nutrition of Sugarcane: Growth, Yield and Quality of Sugarcane as Affected by Soil Phosphorus Levels. Jpn. J. Trop. Agr. 41(2): 52-59.

Alexander D, Mathew T, Deorge B, Sreekumar K, Kuriakose JM and Jayakumar G (2003). Growth and yield of sugarcane as influenced by genotypes and mineral nutrition. Bharatiya Sugar 28 (3): 21-25.

Arif M, Arshad M, Asghar NH and Shahzad MAB (2010). Response of rice (Oryza sativa) genotypes varying in $\mathrm{K}$ use efficiency to various levels of Potassium. International Journal of Agriculture \& Biology 12 (6):926930.

Aulakh MS and Malhi SS (2005). Interactions of nitrogen with other nutrients and water: Effect on crop yield and quality, nutrient use efficiency, carbon sequestration, and environmental pollution. Advances in Agronomy 86: 341-409.

Bationo1 and Anand Kumar K (2002). Phosphorus use efficiency as related to sources of $\mathrm{P}$ fertilizers, rainfall, soil, crop management, and genotypes in the West African semi-arid tropics. Fertilizer Research 26: 89-98,

Bokhtiar S, Roksana MS and Moslehuddin AZM (2015). Soil fertility and productivity of sugarcane influenced by enriched pressmud compost with chemical fertilizers. SAARC Journal of Agriculture 13 (2): 183-197.

Chandel SRS (2002). Hand book of Agricultural Statistics. Achalprakshan mandir, Kanpur. pp17-35.

Dodd RJ and Sharpley N (2015). Recognizing the role of soil organic phosphorus in soil fertility and water quality. Recourses, Conservation and Recycling 105 : 182-193.

Du Toit JL (1962). Fertilizer responses. S AfrSug Ass Exp Stn Ann Rep 63: 18.

Ganga Devi M, Reddy TS, Sumati V, Pratima $\mathrm{T}$ and John K (2012). Nitrogen 
management to improve the nutrient uptake, yield and quality parameters of scented rice under aerobic culture. International Journal of Applied Biology and Pharmaceutical Technology 3 (1).

Ghube NB, Kadlag AD and Kamble BM (2017). Impact of different levels of organic and inorganic fertilizers on growth, yield and quality of preseasonal sugarcane ratoon in Inceptisols. Journal of Applied and Natural Science 9 (2): 812 - 820.

Ghube NB, Kadlag AD and Kamble BM (2017). Impact of different levels of organic and inorganic fertilizers on growth, yield and quality of preseasonal sugarcane ratoon in Inceptisols. Journal of Applied and Natural Science 9 (2): 812 - 820.

Jackson ML (1967). Soil Chemical Analysis. Prentice Hall of India Pvt. Ltd., New Delhi.: pp. 1-485.

Jagman Gothermetorres and William (2017). World Phosphorus Use Efficiency in Cereal Crops. Agronomy journal. 36 : 125.

Kumar V and Verma KS (1999). Influence of phosphorus application on soil available phosphorus, yield and juice quality of sugarcane grown on $\mathrm{P}$ deficient soil. Indian Sugar 39 (8): 579-587.

Lionnet GRE (1997). The effect of factors such as variety and locality on colour and ash in cane. Sugar Milling Research Institute Technical Report No. 1770.

Mahajan G, Timsina J, Jhanji S, Sekhon NK and Singh K (2012). Cultivar response, dry matter partitioning and nitrogen use efficiency. Journal of Crop Improvement 26: 767-790.

McCray JM, Rice RW, Luo Y and Ji. S (2010). Sugarcane Response to Phosphorus Fertilizer on Everglades
Histosols. Agronomy J. 102:14681477.

McCray JMR, Rice W, Luo Y and Ji S (2010). Sugarcane response to phosphorus fertilizer on Everglades Histosols. Agronomy Journal 102:1468-1477.

Meade GP, Chen JCP (1977). Cane Sugar Hand Book (10 ed.). Wiley Inter Science, John Wiley and Sons, New York. pp. 947

Morris DR, Glaz B, Powel G, Deren CM, Snyder GH, Perdomo R and Ulloa MF (2002). Plant nutrition - Sugarcane leaf $\mathrm{P}$ diagnosis in organic soils. Sugarcane International Pp 37.

Oseni LB (1978). Response of sugarcane to source, level and placement of phosphorus in a Histosol. Proceedings of International Symposium on Sugarcane Research and Production NCRI. Pp 8.

Pannu BS, Dang YP, Verma LS and Verma SS (1985). Effect of phosphorus and potassium on yield and quality of sugarcane. Indian Sugar 35 (4): 263265.

Piper CS (1950). Soil and Plant Analysis, Hans Publications, Bombay, India.

Rakkiyappan P, Thangavelu S, Bhagyalakshmi KV (2007). Uptake of nitrogen, phosphorus and potassium by some promising mid late maturing sugarcane clones. Sugar Tech 9 (1) : 23

René PJJ, Rietra, Marius Heinen, Chistian O, Dimkpa and Prem SB (2017). Effects of Nutrient Antagonism and Synergism on Yield and Fertilizer Use Efficiency. Communications in Soil Science and Plant Analysis 48 (6) 1895-1920.

Roy RN, Finck A, Blair GJ and Tandon, HLS (2006). Plant nutrition for food security. A Guide for Integrated Nutrient Management. FAO Fertilizer and Plant Nutrition Bulletin 16. Rome, Italy: FAO 
Sandhu SS and Mahal SS (2014). Performance of rice under different planting methods, nitrogen levels and Scientific Society of Advanced Research and Social Change SSARSC International Journal of Management 3(1): 23496975

Sandhyakanthi M, Raman AV and Ramanmurthy KV (2014). Effect of different crop establishment techniques and nutrient doses on nutrient uptake and yield of rice. Karnataka J. Agric. Sci., 27(3): 293-295.

Sanusan S, Polthanee A, Seripong S, Audebert A and Mouret J (2009). Rates and timing of phosphorus fertilizer on growth and yield of direct seeded rice in rainfed conditions. Soil and Plant Science 59: 491-499.

Schumann AW, Meyer JH and Nair S (1998). Evidence for different nitrogen use efficiencies of selected sugarcane varieties. Proc. S. Afr. Sug. Technol. Ass., 72: 77-80.

Thangavelu S and Chiranjivi Rao K (2002). Phosphorus uptake of some sugarcane genetic stocks and its association with uptake of other nutrients and yield of cane and sugar. Indian Sugar 52: 499606.

Uddin S, Sarkar MAR and Rahman MM (2013). Effect of nitrogen and potassium on yield of dry direct seeded rice cv. Nerica 1 in aus season. International Journal of Agronomy and Plant Production 40 (1): 69-75.

Yuanqiu He, Shen, Q, Kong H, Xiong Y and Wang X (2007). Effect of soil moisture content and phosphorus application on phosphorus nutrition of rice cultivated in different water regime systems. Journal of Plant Nutrition 27(12): 2259-2272.

\section{How to cite this article:}

Rama Lakshmi, Ch.S., A. Sireesha, T. Sreelatha, P. Jamuna and Bharatha Lakshmi, M. 2019. Soil Test based Phosphorus Nutrition as Cost Reduction Technology in Sugarcane. Int.J.Curr.Microbiol.App.Sci. 8(11): 167-176. doi: https://doi.org/10.20546/ijcmas.2019.811.021 